\title{
The role of the cytoskeleton in capacitative calcium entry in myenteric glia
}

T. LIN, W. ZHANG, R. GARRIDO, B. SEGURA, Y. HU, E. GUZMAN \& M. MULHOLLAND

Department of Surgery, University of Michigan Medical Center, Ann Arbor, Michigan, USA

\begin{abstract}
Capacitative calcium entry (CCE) is the process by which intracellular calcium is replenished from the external milieu upon depletion of intracellular stores. CCE is thought to participate in chemotaxis, proliferation and cell signalling. A physical interaction between intracellular stores and the plasma membrane is postulated to regulate CCE. We hypothesized that cytoskeletal disruption alters this interaction, inhibiting CCE in enteric glia. Cultured myenteric glia from neonatal guinea-pigs were treated with cytochalasin $D$ $\left(10 \mu \mathrm{mol} \mathrm{L}{ }^{-1}\right), a$ microfilament disrupting agent, nocodazole $\left(20 \mu \mathrm{mol} \mathrm{L} \mathrm{L}^{-1}\right)$, a microtubule disrupting agent, or vehicle (dimethyl sulphoxide). Intracellular calcium changes were measured using fura-2 microfluorimetry. To evaluate the rate of cation re-entry, barium was substituted for calcium because barium is not sequestered internally. Cytochalasin D-treated glia had diminished CCE responses $\left(57 \pm 3 \mathrm{nmol} \mathrm{L}^{-1}\right)$ compared with controls $\left(97 \pm 7 \mathrm{nmol} \mathrm{L}^{-1}\right)$ as did nocodazole-treated glia $\left(30 \pm 2 \mathrm{nmol} \mathrm{L^{-1 }}\right)$ vs controls $\left(77 \pm 6 \mathrm{nmol} \mathrm{L} \mathrm{L}^{-1}\right)$. The proportion of cells demonstrating CCE abolition was greater in the cytochalasin $(50 \pm 8 \%)$ and nocodazole-treated $(89 \pm 2 \%)$ groups compared with controls $(21 \pm 2 \%, 40 \pm 9 \%$, respectively). Cytochalasin $D$ and nocodazole treatment diminished the rate of cation re-entry based on diminished barium entry in treated vs control cells. From this study, we conclude that disruption of cytoskeletal elements diminishes calcium influx essential to calcium store repletion in myenteric glia.
\end{abstract}

Keywords capacitative calcium entry, cytochalasin, enteric glia, nocodazole.

Address for correspondence

Michael Mulholland, M.D., Ph.D.,

2101 Taubman Center, 1500 E Medical Center Drive,

Ann Arbor, MI 48109-0346, USA.

Tel.: (734) 936-3236; fax: (734) 763-5615;

e-mail: micham@umich.edu

Received: 13 January 2003

Accepted for publication: 17 February 2003

\section{INTRODUCTION}

The enteric nervous system (ENS) is a major regulator of gastrointestinal function with a diversity of control ranging from regulation of blood flow to motility. The ENS spans the length of the gastrointestinal tract and is situated between the muscular layers of the gut. Two major cell types comprise the ENS, neurones and glial cells. Glia have long been regarded to serve predominantly adjunctive roles in support of neurones within the ENS. A growing body of evidence, however, suggests that glia have an important role within the ENS environment. ${ }^{1}$ Ruhl et al. have demonstrated that cultured myenteric glia are responsive to interleukin- $1 \beta$ by producing interleukin-6. ${ }^{2}$ Maudlej and Hanani showed dye coupling among enteric glia. ${ }^{3}$ Studies from our laboratory have shown that within the ENS, myenteric glia participate in intercellular communication amongst glial cells via calcium wave propagation. ${ }^{4}$ Preliminary data from these ongoing studies also suggests the propagation of waves between enteric neurones and glia (Zhang et al.). We postulate that the ability of myenteric glia to respond to molecules through established signal transduction pathways may be essential to the functionality of the ENS. Previous work from our laboratory has demonstrated that enteric glia are responsive to a number of neuroligands including adenosine triphosphate (ATP), bradykinin, histamine and endothelin through calcium signalling. ${ }^{5,6}$

Enteric glia demonstrate capacitative calcium entry $(\mathrm{CCE})$, a component of cellular calcium regulation, first proposed by Putney. ${ }^{7,8}$ In $\mathrm{CCE}$, intracellular calcium is replenished by calcium entry from the extracellular milieu upon intracellular calcium store depletion. CCE has been demonstrated in numerous cells types and is regarded to be characteristic of predominantly non-excitable cells. CCE is postulated to participate in processes as disparate as signal transduction, chemotaxis, and proliferation, possibly 
through the ability to sustain agonist-induced calcium transients or calcium oscillations. ${ }^{9}, 10$

The mechanism by which calcium entry is stimulated by the depletion of intracellular calcium stores has been the focus of intense investigation. ${ }^{11}$ Proposed mechanisms of CCE include: a diffusible signalling molecule, transport of a CCE channel to the plasma membrane after store depletion, gating of plasma membrane-based CCE channels by localized calcium concentration gradients, and physical coupling between the intracellular calcium storage organelle and plasma membrane calcium channels. ${ }^{12}$ The last, "conformational coupling' model, has been the focus of a number of recent studies. Delmas et al. showed that disruption of the actin cytoskeleton resulted in a loss of coupling between a plasma membrane bradykinin receptor and the IP3 receptor, causing inactivation of Trp, a potential CCE channel. ${ }^{13}$ Other studies involving disruption of protein-protein interactions between the calcium storage organelle and the plasma membrane by destabilizing cytoskeletal elements (microfilaments and microtubules) have yielded conflicting results. ${ }^{14,15}$

The potential relationship of the cellular cytoskeletal architecture to the mechanisms of CCE in enteric glia has not been reported. We sought to investigate the role of the cytoskeleton in the regulation of CCE in enteric glia by pharmacological disruption of actin microfilaments with cytochalasin D or tubulin microtubules with nocodazole. The results of this study demonstrate that the cytoskeleton is integral to CCE regulation in enteric glia.

\section{MATERIALS AND METHODS}

\section{Materials}

Fura-2 acetoxymethyl ester (fura-2/AM), fura-2 free acid, Alexa Fluor ${ }^{\circledR} 488$ phalloidin, and 4',6-diamidino2-phenylindole, dihydrochloride (DAPI) were obtained from Molecular Probes (Eugene, OR, USA). ATP, collagenase type IV, trypsin-ethylenediaminetetraacetic acid (EDTA), soya bean trypsin inhibitor (type I-S), penicillin-streptomycin solution, HEPES, dimethyl sulphoxide, glucose ethylene-bis (oxyeth yenenitrilo) tetraacetic acid, EGTA, barium, cytochalasin D and nocodazole were purchased from Sigma Chemical (St Louis, MO, USA). Anti- $\beta$-tubulin antibody and goat anti-mouse IgG-FITC secondary antibody were obtained from Santa Cruz Biotechnology (Santa Cruz, CA, USA). Goat normal serum was from Vector Laboratories (Burlingame, CA, USA).

Hank's balanced salt solution, medium 199, L-glutamine, MEM amino acids, HEPES, and sodium pyruvate were from Gibco BRL (Grand Island, NY, USA). NU-serum $I^{\circledR}$ was from Becton Dickinson (Bedford, MA, USA). Two-day-old male DuncanHartley guinea-pigs were obtained from Simonsen Labs (Gilroy, CA, USA).

\section{Cultures of myenteric glia}

Dispersed primary cultures of guinea-pig myenteric glia were prepared on collagen-coated coverslips and used for experiments within 5-8 days. In brief, the taenia coli from 2-day-old male Duncan-Hartley guinea-pigs were removed from the caecum and placed in Hank's balanced salt solution plus $0.1 \%$ collagenase (type IV) for $16-20 \mathrm{~h}$ at $4{ }^{\circ} \mathrm{C}$. After 35 -min incubation at $37^{\circ} \mathrm{C}$, the myenteric plexus of the taenia coli was separated from the investing muscle layers under a dissecting microscope. The plexus was incubated for $30 \mathrm{~min}$ at $37^{\circ} \mathrm{C}$ using trypsin-EDTA $\left(0.5 \mathrm{~g} / \mathrm{L}\right.$ trypsin, $0.5 \mathrm{mmol} \mathrm{L}^{-1}$ EDTA) solution, triturated with pipettes of decreasing tip diameter, and plated on collagen-coated coverslips. Cultures were maintained in medium 199 supplemented with $5 \%$ NU-serum ${ }^{\circledR}, 1 \mathrm{mmol} \mathrm{L}^{-1}$ sodium pyruvate, glucose $5 \mathrm{mg} / \mathrm{ml}, 0.2 \mathrm{mmol} \mathrm{L}^{-1}$ L-glutamine, and $0.001 \%$ trypsin inhibitor (type I-S from soya bean). Penicillin-streptomycin solution was added for the first $48 \mathrm{~h}$ at $2 \%$ concentration. Thereafter, media, devoid of antibiotics, was changed every other day. No antimitotic agents were used. The cultures were incubated at $37{ }^{\circ} \mathrm{C}$ with $5 \% \mathrm{CO}_{2}$ and used for study within 5-8 days of preparation.

\section{Solutions}

All experiments were performed in standardized solutions except when noted. Standard calcium control buffer was a modified Krebs-Ringer solution containing $118 \mathrm{mmol} \mathrm{L}^{-1} \mathrm{NaCl}, 4.7 \mathrm{mmol} \mathrm{L}^{-1} \mathrm{KCl}, 1.8 \mathrm{mmol} \mathrm{L}^{-1}$ $\mathrm{CaCl}_{2}, \quad 10 \mathrm{mmol} \mathrm{L}^{-1} \quad$ 4-(2-hydroxyethyl)piperazine1-ethane sulfonic acid HEPES, $15 \mathrm{mmol} \mathrm{L}{ }^{-1} \mathrm{NaHCO}_{3}$, $11 \mathrm{mmol} \mathrm{L}^{-1}$ glucose, $0.9 \mathrm{mmol} \mathrm{L}^{-1} \quad \mathrm{NaH}_{2} \mathrm{PO}_{3}$, $0.8 \mathrm{mmol} \mathrm{L}^{-1} \mathrm{MgSO}_{4}, \mathrm{pH}$ 7.40. For calcium-free control buffer, $\mathrm{CaCl}_{2}$ was removed and $1 \mathrm{mmol} \mathrm{L}^{-1}$ EGTA was added. In experiments in which barium $\left(4 \mathrm{mmol} \mathrm{L}^{-1}\right.$ ) was used, $\mathrm{HCO}_{3}^{-}, \mathrm{S}_{2} \mathrm{O}_{4}^{2-}$, and $\mathrm{H}_{2} \mathrm{PO}_{4}^{-}$ were removed as they form insoluble salts with barium.

\section{Cytoskeletal disruption}

To investigate the effect of cytoskeletal disruption on CCE regulation, cytochalasin D $\left(0.1-10 \mu \mathrm{mol} \mathrm{L}^{-1}\right)$ or nocodazole $\left(1-20 \mu \mathrm{mol} \mathrm{L}^{-1}\right)$ was added to culture media to disrupt actin microfilaments and tubulin 
microtubules, respectively. ${ }^{15,16}$ Dimethyl sulphoxide (DMSO) was added to glial culture media as a control. The amount of DMSO added as vehicle did not exceed $1 \%$. For microfilament experiments, cytochalasin D-treated and control groups were incubated at $37^{\circ} \mathrm{C}$ for $40 \mathrm{~min}$. For the microtubule experiments, nocodazole-treated and control groups were incubated at $37^{\circ} \mathrm{C}$ for $120 \mathrm{~min}$. Cells were examined using phase contrast microscopy for evidence of cytoskeletal disruption prior to calcium imaging. Incubation of glia with cytochalasin D or nocodazole for the times of 40 and $120 \mathrm{~min}$, respectively, were determined by assessing for evidence of morphologic change at multiple time points after drug treatment under light microscopy. Evidence of structural change was most consistently reproduced at the selected times, 40 and $120 \mathrm{~min}$.

\section{Loading and cell preparation for imaging}

Treated and control glia were incubated at $37^{\circ} \mathrm{C}$ in fresh warmed media containing $0.5 \mu \mathrm{mol} \mathrm{L}^{-1}$ fura-2-AM for $45 \mathrm{~min}$ following treatment. Loaded coverslips were washed, resuspended in calcium control buffer, and placed in a Lucite superfusion chamber on a warmed $\left(37^{\circ} \mathrm{C}\right)$ microscope stage. In all experiments, the rate of superfusion was constant at $1 \mathrm{~mL} \mathrm{~min}^{-1}$ and maintained at $37^{\circ} \mathrm{C}$.

\section{Intracellular calcium measurement}

Single-cell intracellular calcium measurements were performed on treated and control glia using fura-2based fluorimetry. A Zeiss Axiovert inverted microscope and Attofluor ${ }^{\circledR}$ digital imaging system (Rockville, MD, USA) were used for single-cell intracellular calcium $\left(\left[\mathrm{Ca}^{2+}\right]_{i}\right)$ measurements. $\left[\mathrm{Ca}^{2+}\right]_{\mathrm{i}}$ was determined from the ratio of fluorescence intensity of fura- 2 at 334 and $380 \mathrm{nmol} \mathrm{L}^{-1}$, with an emission wavelength of $540 \mathrm{nmol} \mathrm{L}^{-1}$. Calibration of the system was performed with the two-point standardization equation using fura-2-free acid:

$$
\left[\mathrm{Ca}^{2+}\right]_{\mathrm{i}}=\mathrm{K}_{\mathrm{d}}\left[\left(R-R_{\mathrm{Lo}}\right) /\left(R_{\mathrm{Hi}}-R\right)\right] b
$$

where $\mathrm{K}_{\mathrm{d}}=$ dissociation constant of the $\mathrm{Ca}^{2+} /$ fura- 2 complex $\left(225 \mathrm{nmol} \mathrm{L}^{-1}\right), R=F_{334} / F_{380}$, i.e. the fluorescence at 334-nm excitation divided by the fluorescence at $380-\mathrm{nm}$ excitation, $R_{\mathrm{Lo}}=$ ratio at zero calcium $\left(1 \mathrm{mmol} \mathrm{L}{ }^{-1}\right.$ EGTA), $R_{\mathrm{Hi}}=$ ratio at high cal$\operatorname{cium}\left(1 \mathrm{mmol} \mathrm{L}^{-1} \mathrm{CaCl}_{2}\right)$, and $b=F_{380}\left(\right.$ zero $\left.\mathrm{Ca}^{2+}\right) / F_{380}$ $\left(\right.$ saturating $\left.\mathrm{Ca}^{2+}\right)$. A ratio pair was measured every $1.5 \mathrm{~s}$.
To elicit CCE, a standardized protocol was utilized. ${ }^{5,7}$ All cells were initially exposed to calcium control buffer and then placed in calcium-free buffer containing EGTA. Cells were exposed to ATP $\left(100 \mu \mathrm{mol} \mathrm{L}^{-1}\right)$, a known IP3-mediated calciummobilizing agonist, in the absence of calcium for $200 \mathrm{~s}$, followed by calcium-free buffer containing EGTA. ${ }^{6}$ Calcium was then returned to the extracellular environment for the remainder of the experiment.

In a separate group of experiments, barium $\left(4 \mathrm{mmol} \mathrm{L}^{-1}\right)$ was substituted for calcium to characterize ion entry into glial cells after treatment with vehicle, cytochalasin $\mathrm{D}$, or nocodazole. Barium ions cause fura-2 fluorescence ratio changes in a similar manner to calcium ions. Barium, in contrast to calcium, cannot be sequestered in internal stores and thus is representative of cation entry from extracellular sources. ${ }^{7}$ In these experiments, the imaging system was not calibrated and the data were recorded as the ratio of $F_{334}$ to $F_{380}$.

\section{Fluorescence microscopy}

Primary glial cells grown on coverslips treated for the respective times with vehicle, cytochalasin D $\left(10 \mu \mathrm{mol} \mathrm{L}^{-1}\right)$, or nocodazole $\left.(20 \mu \mathrm{mol} \mathrm{L})^{-1}\right)$ were fixed in $4 \%$ para-formaldehyde in phosphate-buffered saline (PBS) at $4{ }^{\circ} \mathrm{C}$, washed twice in PBS, then permeabilized with $0.1 \%$ Triton $\mathrm{X}-100$ for $5 \mathrm{~min}$ at room temperature. To define the actin microfilaments in control and cytochalasin D-treated cells, Alexa Fluor ${ }^{\circledR} 488$ phalloidin (Molecular Probes Eugene, OR, USA) was used. Phalloidin, derived from the Amanita phalloides mushroom, binds competitively to F-actin and acts as a specific F-actin probe. This probe has been used to specifically stain F-actin in a study by Yamamoto and Kiss. ${ }^{17}$ In accordance with the manufacturer's staining protocol, a $1: 40$ dilution of Alexa Fluor ${ }^{\circledR} 488$ phalloidin was used to stain microfilaments. To reduce nonspecific staining, $1 \%$ bovine serum albumin (BSA) was added to the staining solution. Coverslips were stained for $20 \mathrm{~min}$ at room temperature and subsequently washed at least twice with PBS. For microtubule staining, a monoclonal antibody against $\beta$-tubulin was employed (Santa Cruz Biotechnology, Inc., Santa Cruz, CA, USA) in analogy to similar probes used to specifically stain $\beta$-tubulin. ${ }^{15,18}$ Fixed control and nocodazole-treated cells were incubated in $10 \%$ normal blocking serum made with goat normal serum (Vector Laboratories, Burlingame, CA, USA) for $20 \mathrm{~min}$ at room temperature to suppress non-specific binding. 
After washing in PBS, cells were incubated with anti- $\beta$ tubulin antibody overnight at $4{ }^{\circ} \mathrm{C}$. Secondary antibody, goat anti-mouse IgG-FITC, was diluted $1: 50$ and coverslips were incubated for $1 \mathrm{~h}$ at room temperature. Coverslips were washed twice in PBS. Cells were then treated with 4',6-diamidino-2-phenylindole, dihydrochloride (DAPI) as a nuclear counterstain at $1: 300$ dilution for $5 \mathrm{~min}$. Coverslips were mounted on glass slides and stored in a light-impermeant box until examination using an AxioVision ${ }^{\circledR}$ (Carl Zeiss International, Thornwood, NY, USA) software-based Zeiss Axiophot-2 fluorescent microscope equipped with a Zeiss Axiocam digital camera for image capturing.

\section{Data analysis and presentation}

Data are expressed as mean \pm SEM. Experiments were performed for control and treated groups from at least three different culture preparations. Each culture preparation required at least three animals. Only one microscope field per coverslip was examined. Individual cells within a microscopic field were studied by using Attofluor Ratiovision ${ }^{\circledR}$ (Atto Bioscience, Rockville, MD, USA) software, version 6.00 , which allowed for selection of individual regions of interest to be examined. Cells with basal $\left[\mathrm{Ca}^{2+}\right]_{\mathrm{i}}>100 \mathrm{nmol} \mathrm{L}{ }^{-1}$ were excluded as glia with high $\left[\mathrm{Ca}^{2+}\right]_{\mathrm{i}}$ prior to any stimulation were considered to be damaged or leaky. Cells were considered responsive if their response to ATP was $>50 \mathrm{nmol} \mathrm{L}^{-1}$ over baseline. CCE was defined by the rise in $\left[\mathrm{Ca}^{2+}\right]_{i}$ that occurred after the return of calcium to the extracellular environment after the depletion of internal stores in the absence of extracellular calcium. The increment of CCE $(\Delta$ calcium) was determined by measuring the peak and baseline $\left[\mathrm{Ca}^{2+}\right]_{\mathrm{i}}$ and calculating the difference. In this study, we defined a cell to have an inhibited CCE response when $\Delta$ calcium $<50 \mathrm{nmol} \mathrm{L}^{-1}$. To quantitatively assess the proportion of cells in treated and control groups with inhibited CCE responses, the number of cells with $\Delta$ calcium $<50 \mathrm{nmol} \mathrm{L}^{-1}$ was compared with the total number of responsive cells within a given set of cultures. These data were represented as percentage of cells inhibited. In the barium influx measurements, the rate of entry was determined by calculating the slope, which was defined as the change in ratio of $F_{334}$ to $F_{380}$ over a constant time interval (250 s). The slope was designated in arbitrary units. One-way ANOvA and Student's unpaired $t$-test were carried out using GraphPad Prism version 3.02 (Graphpad Software, San Diego, CA, USA) to determine statistical significance. $P$ values $<0.05$ were considered significant. In this study, $n$ equals the number of cells examined, except in data represented as percentage of cells inhibited, where $n$ equals the number of separate culture preparations.

\section{RESULTS}

\section{Enteric glia are responsive to ATP and demonstrate CCE}

Enteric glia have been shown from previous work to be responsive to ATP with mobilization of internal calcium stores through an IP3-mediated pathway, inducing capacitative entry when calcium is returned to the external environment. ${ }^{5,7}$ We used this established protocol as the basis for the experiments in this study. Cultured glia were exposed to $100 \mu \mathrm{mol} \mathrm{L}^{-1}$ ATP, prepared in calcium-free buffer, for $200 \mathrm{~s}$ to induce release of calcium from intracellular stores. $\left[\mathrm{Ca}^{2+}\right]_{\mathrm{i}}$ was allowed to return to basal levels subsequent to the agonist-induced calcium transient. Cells were returned to calcium-free buffer and then extracellular calcium was reintroduced into the perfusion with control calcium buffer. Fig. 1 is a representative tracing of a single control glial cell typical of this protocol.

We used ATP in this investigation based on previous work performed in our laboratory by Kimball and Mulholland. ${ }^{6}$ In our experience, ATP consistently elicits an increase in intracellular calcium concentration in nearly $100 \%$ of cells whereas bradykinin has been shown to elicit an increase in intracellular calcium concentration in only $11 \%$ of cultured myenteric glia. ${ }^{6}$ Hence, we believe that the use of ATP over other ligands would provide the greatest possibility of

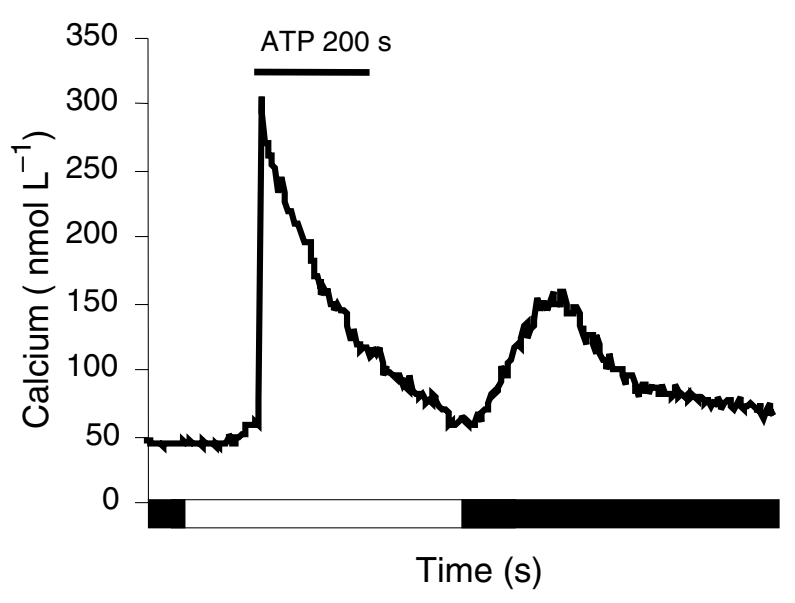

Figure 1 Representative tracing of enteric glia exposed to adenosine triphosphate $\left(100 \mu \mathrm{mol} \mathrm{L}{ }^{-1}\right)$ for $200 \mathrm{~s}$ in calciumfree buffer (white bar). Addition of extracellular calcium (black bar) to perfusion medium induces capacitative calcium entry. Tracing represents a single glial cell. 
studying as many responsive glia as possible in our assays.

\section{Morphological changes in myenteric glia following cytoskeletal disruption}

To examine the effect of altering the cytoskeleton of myenteric glia on CCE, actin microfilaments were disrupted using cytochalasin D. Cytochalasin D is an alkaloid produced by Helminthosporium and other moulds which acts to destabilize F-actin by binding to G-actin, the monomeric form of actin, thus creating a state of G-actin depletion. As turnover and re-polymerization are constantly occurring within cells, existing F-actin depolymerizes as the effective concentration of free G-actin becomes limiting. ${ }^{14}$ Glial cells were pretreated with $10 \mu \mathrm{mol} \mathrm{L}^{-1}$ cytochalasin $\mathrm{D}$ for $40 \mathrm{~min}$ at $37^{\circ} \mathrm{C}$. Control glia were incubated with an equal volume of vehicle, DMSO, under the same conditions. Both groups were examined with phase contrast microscopy as shown in Fig. 2. Control glia were round-shaped with comparable nuclear and cytoplasmic volumes (Fig. 2C). In contrast, cytochalasin D-treated glia were spiculated and condensed with loss of significant amounts of cytoplasmic volume (Fig. 2D). The cytoskeletal disruption was more clearly defined with fluorescent staining of F-actin with Alexa Fluor $^{\circledR} 488$ phalloidin (Fig. 3).

The microtubule cytoskeletal network was similarly investigated using nocodazole, which binds to $\beta$-tubulin and induces microtubule depolymerization. ${ }^{16}$ Glial cells were pretreated with $20 \mu \mathrm{mol} \mathrm{L}^{-1}$ nocodazole for $120 \mathrm{~min}$ at $37^{\circ} \mathrm{C}$. Control glia were incubated with an equal volume of vehicle, DMSO, under the same conditions. Immunocytochemical staining with anti- $\beta$-tubulin antibody revealed the microtubule organization in control cells. Staining appeared more sparse and perinuclear in nocodazole- treated glia compared with vehicle-treated controls (Fig. 4).

\section{Effect of cytochalasin D on enteric glial CCE}

To discern whether cytochalasin $\mathrm{D}$ has a dose-dependent effect on glial CCE, increasing doses of cytochala$\sin \mathrm{D}\left(0.1,1,10 \mu \mathrm{mol} \mathrm{L}^{-1}\right)$ were used to treat glia for $40 \mathrm{~min}$ at $37^{\circ} \mathrm{C}$. Evidence of cytoskeletal disruption was assessed by light microscopy (data not shown). Control cells treated with vehicle were examined in
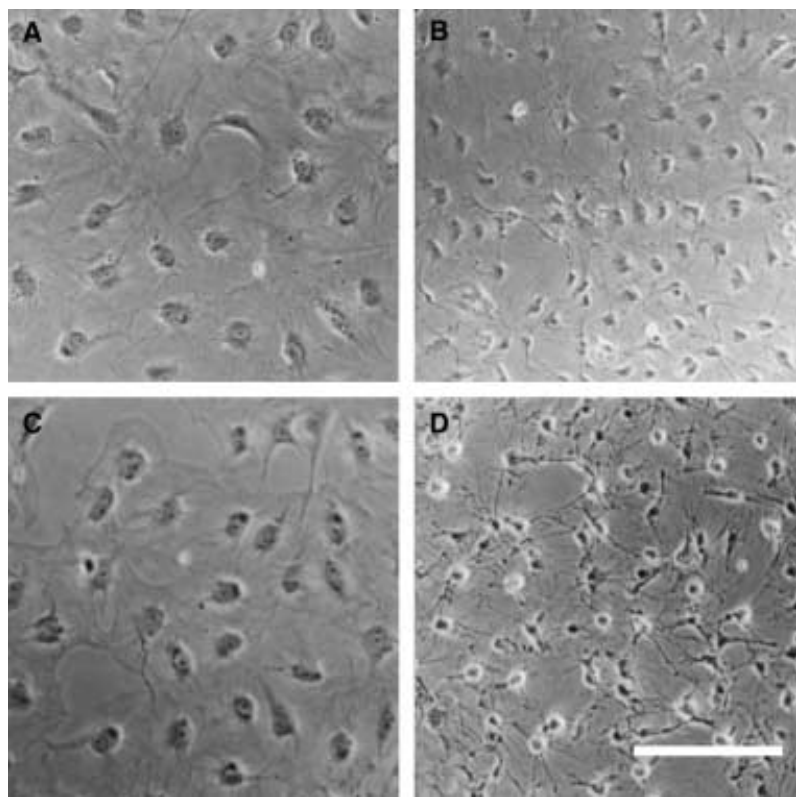

Figure 2 Light photomicrograph of enteric glia exposed to vehicle (control) or cytochalasin $\mathrm{D}\left(10 \mu \mathrm{mol} \mathrm{L}^{-1}\right)$ at $20 \times$ magnification. Scale bar represents $25 \mu \mathrm{m}$. (A) Control, time $0 \mathrm{~min}$; (B) cytochalasin D-treated cells, time 0 min; (C) control cells after $40 \mathrm{~min}$; and (D) cytochalasin D-treated cells after $40 \mathrm{~min}$.
Figure 3 Fluorescent staining of actin microfilaments with AlexaFluor ${ }^{\circledR} 488$ phalloidin using fluorescent microscopy at $40 \times$ magnification. Scale bar represents $10 \mu \mathrm{m}$. (A) Control (vehicle-treated) cells; and (B) cytochalasin D $\left.(10 \mu \mathrm{mol} \mathrm{L})^{-1}\right)$ treated cells with marked condensation of microfilaments.
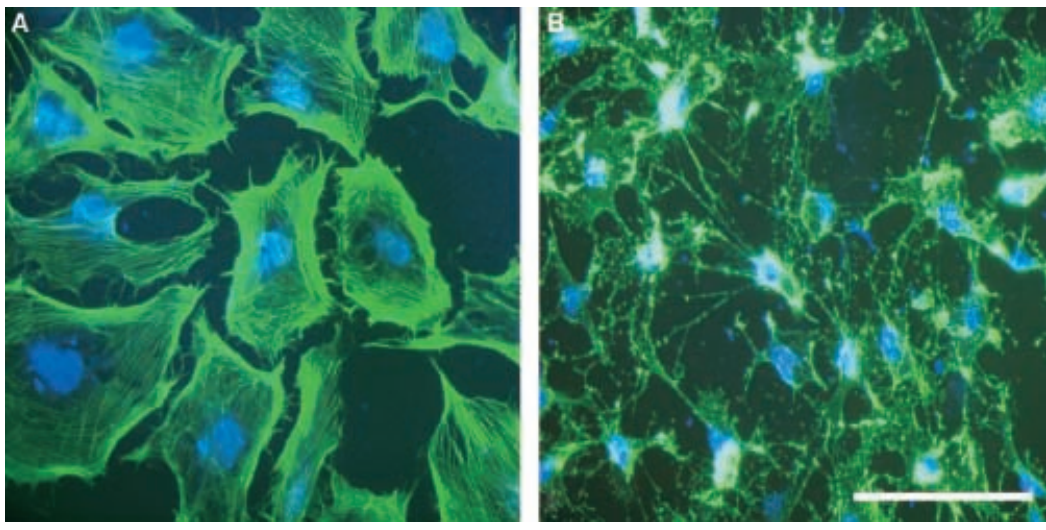

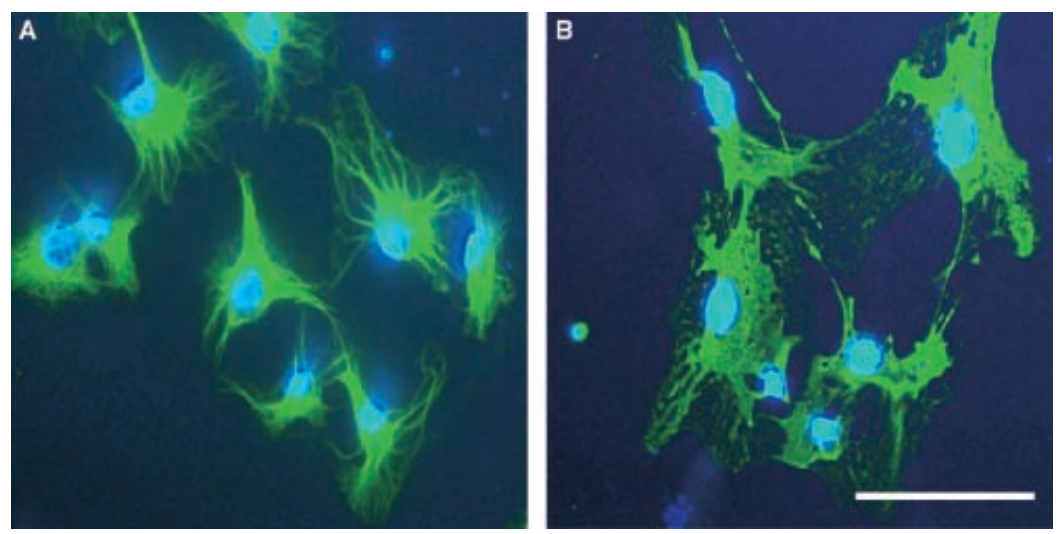

Figure 4 Immunocytochemical staining of microtubules with anti- $\beta$-tubulin antibody using fluorescent microscopy at $40 \times$ magnification. Scale bar represents $10 \mu \mathrm{m}$. (A) Control (vehicle-treated) cells with diffuse microtubule staining; and (B) nocodazole-treated cells with condensed pattern of staining away from the cell periphery.

parallel. Intracellular calcium levels were measured according to the previously mentioned perfusion protocol. The changes in calcium influx in control vs cytochalasin D-treated glia are shown in Fig. 5. Control cells had $\Delta$ calcium due to CCE of $88.5 \pm 5 \mathrm{nmol} \mathrm{L}^{-1}$ whereas cytochalasin $\mathrm{D}$ treatment yielded CCE of $69.3 \pm 5 \mathrm{nmol} \mathrm{L}^{-1} \quad\left(0.1 \mu \mathrm{mol} \mathrm{L}^{-1}\right), \quad 62.5 \pm 9 \mathrm{nmol} \mathrm{L}^{-1}$ $\left(1 \mu \mathrm{mol} \mathrm{L}^{-1}\right)$ and $54.29 \pm 3 \mathrm{nmol} \mathrm{L}^{-1} \quad\left(10 \mu \mathrm{mol} \mathrm{L}^{-1}\right)$. Although there appeared to be a qualitative dosedependent decrease in CCE by cytochalasin D treatment, statistical significance was achieved only in the $10 \mu \mathrm{mol} \mathrm{L}^{-1}$ group $(P<0.01$ vs control).

Given these findings, we pursued the effect on CCE by disruption of actin microfilaments using $10 \mu \mathrm{mol} \mathrm{L}^{-1}$ cytochalasin D. Basal $\left[\mathrm{Ca}^{2+}\right]_{i}$ levels were similar in control and treated groups $\left(33 \pm 1 \mathrm{nmol} \mathrm{L}^{-1}\right.$ vs $\left.30 \pm 0.6 \mathrm{nmol} \mathrm{L}^{-1}\right)$. Cytochalasin D-treated cells demonstrated a diminished CCE response $\left(57 \pm 3 \mathrm{nmol} \mathrm{L}^{-1}\right.$, $n=205$ cells) compared with vehicle-treated controls $\left(97 \pm 7 \mathrm{nmol} \mathrm{L}{ }^{-1}, n=111\right.$ cells, $\left.P<0.01\right)$ (Fig. 6A,B).

As mentioned earlier, inhibition of the CCE response was arbitrarily defined as a change in calcium entry of $<50 \mathrm{nmol} \mathrm{L}^{-1}$. Determination of the number of cells examined meeting this criteria revealed the proportion of cells demonstrating CCE inhibition in the cytochalasin D-treated $\left(10 \mu \mathrm{mol} \mathrm{L}^{-1}\right)$ group $(50 \pm 8 \%, n=6$ separate culture preparations) was significantly greater than the proportion of cells demonstrating CCE inhibition in the control group $(21 \pm 2 \%, n=3$ separate culture preparations, $P<0.05$ ) (Fig. 6C).

\section{Effect of nocodazole on enteric glial CCE}

To discern whether nocodazole exhibits a dose-dependent effect on glial CCE, increasing doses of nocodazole $\left(1,10,20 \mu \mathrm{mol} \mathrm{L}{ }^{-1}\right)$ were used to treat glia for $120 \mathrm{~min}$ at $37^{\circ} \mathrm{C}$. Evidence of cytoskeletal disruption was assessed by light microscopy (data not shown). Control cells

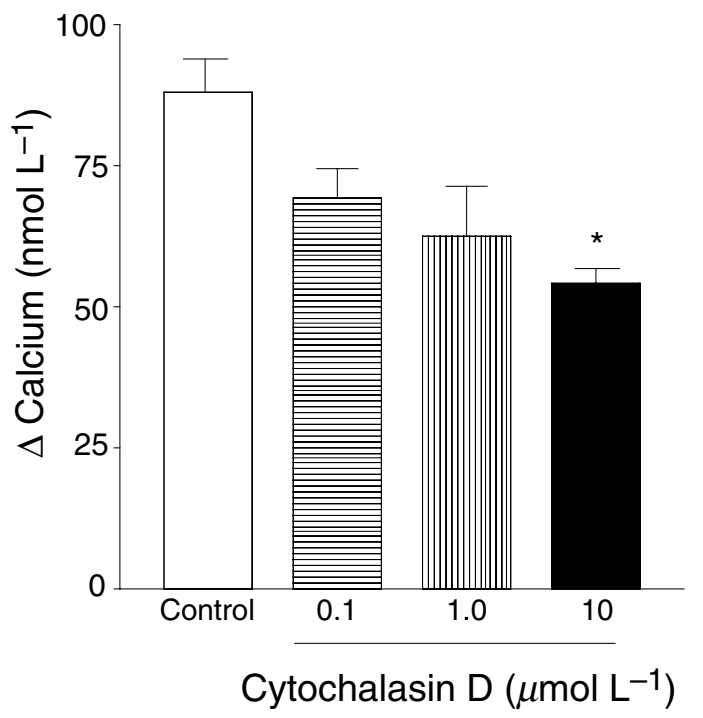

Figure 5 Effect of increasing cytochalasin D dose on capacitative calcium entry (CCE). Change in intracellular calcium due to CCE in control (white bar) compared with 0.1, 1.0 and $10 \mu \mathrm{mol} \mathrm{L}{ }^{-1}$ cytochalasin D after $40 \mathrm{~min}$ at $37^{\circ} \mathrm{C}$. Control cells had an increment of CCE ( $\Delta$ calcium) due to CCE of $88.5 \pm 5 \mathrm{nmol} \mathrm{L}^{-1}$ whereas cytochalasin $\mathrm{D}$ treatment yielded CCE of $69.3 \pm 5 \mathrm{nmol} \mathrm{L}^{-1}\left(0.1 \mu \mathrm{mol} \mathrm{L}^{-1}\right.$, ANOva $P>0.05 \mathrm{vs}$ control), $62.5 \pm 9 \mathrm{nmol} \mathrm{L}^{-1}\left(1 \mu \mathrm{mol} \mathrm{L}{ }^{-1}\right.$, ANOva $P>0.05$ vs control $)$ and $54.29 \pm 3 \mathrm{nmol} \mathrm{L}^{-1}\left(10 \mu \mathrm{mol} \mathrm{L}^{-1}\right.$, ANOvA

${ }^{\star} P<0.01$ vs control). More than 50 cells were examined in each control and treatment group from at least three separate culture preparations.

treated with vehicle were examined in parallel. Intracellular calcium levels were measured. The change in calcium influx in control vs nocodazole-treated glia is shown in Fig. 7. Control cells had $\Delta$ calcium due to CCE of $63.9 \pm 4 \mathrm{nmol} \mathrm{L}^{-1}$ whereas nocodazole treatment yielded CCE of $31.0 \pm 3 \mathrm{nmol} \mathrm{L}^{-1} \quad\left(1 \mu \mathrm{mol} \mathrm{L}^{-1}\right)$, $29.7 \pm 3 \mathrm{nmol} \mathrm{L}^{-1}\left(10 \mu \mathrm{mol} \mathrm{L}^{-1}\right)$ and $25.8 \pm 2 \mathrm{nmol} \mathrm{L}^{-1}$ 
A

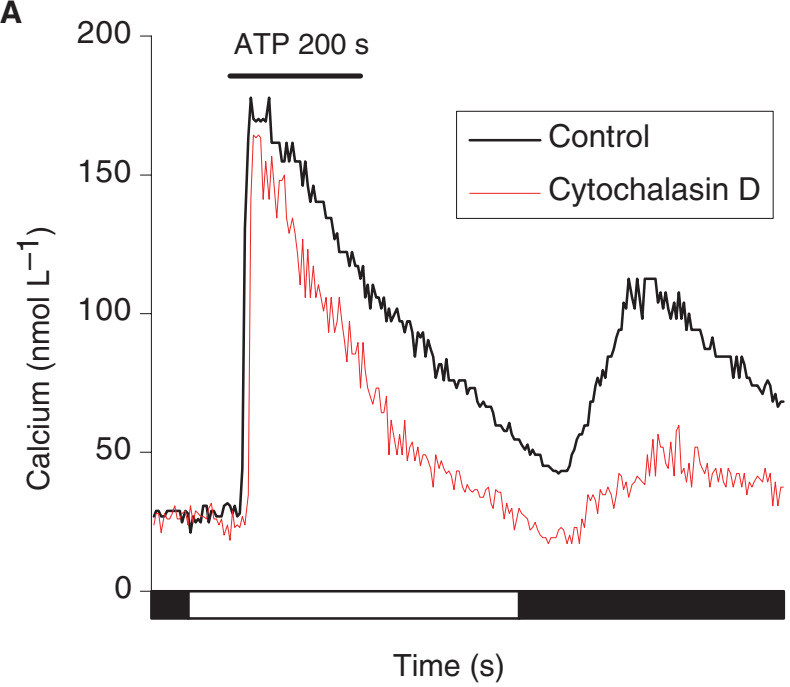

B

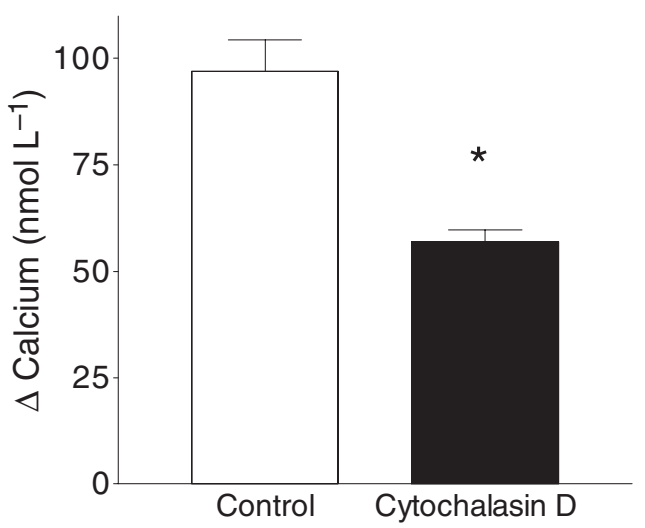

C

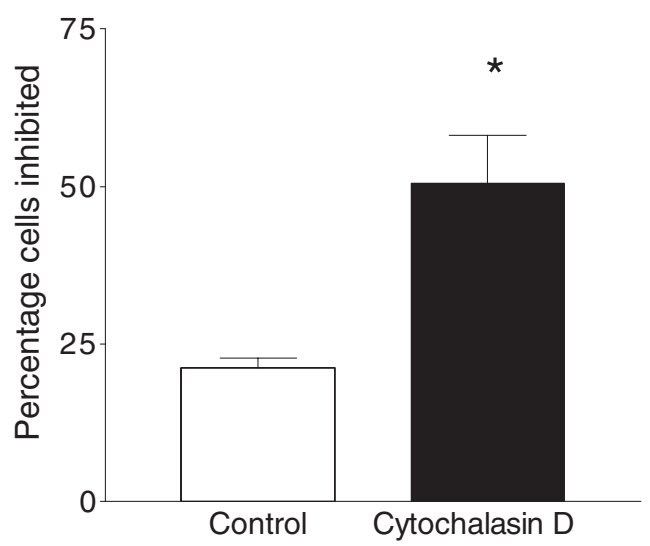

$\left(20 \mu \mathrm{mol} \mathrm{L}^{-1}\right)$. Although there appeared to be an inhibitory effect on CCE with these doses of nocodazole, there was no clear graded dose responsiveness $(P<0.01$ in $1,10,20 \mu \mathrm{mol} \mathrm{L}{ }^{-1}$ vs control). Given the lack of clear dose-dependent inhibition with nocodazole, we conducted the remainder of the experiments with $20 \mu \mathrm{mol} \mathrm{L}{ }^{-1}$ nocodazole for $120 \mathrm{~min}$. Basal $\left[\mathrm{Ca}^{2+}\right]_{\mathrm{i}}$ levels
Figure 6 Effect of cytochalasin D treatment on capacitative calcium entry (CCE). (A) Representative single cell tracing of enteric glia (control - black tracing; cytochalasin D - red tracing). Cells were initially exposed to adenosine triphosphate $\left(100 \mu \mathrm{mol} \mathrm{L}^{-1}\right)$ for $200 \mathrm{~s}$ in calcium-free buffer (white bar). Calcium was returned to the medium (black bar) with a second peak due to CCE. (B) Cytochalasin D-treated cells (black bar, $57 \pm 3 \mathrm{nmol} \mathrm{L}^{-1}, n=205$ cells, ${ }^{\star} P<0.01$ ) demonstrated a diminished CCE response compared with control cells (white bar, $97 \pm 7 \mathrm{nmol} \mathrm{L}{ }^{-1}, n=111$ cells). Cells examined were from at least three separate preparations.

(C) Cytochalasin D-treated cells demonstrated a greater proportion of cells with inhibited CCE $\left(50 \pm 8 \%,{ }^{\star} P<0.05, n=6\right.$ separate culture preparations) compared with control cells (21 $\pm 2 \%, n=3$ separate culture preparations).

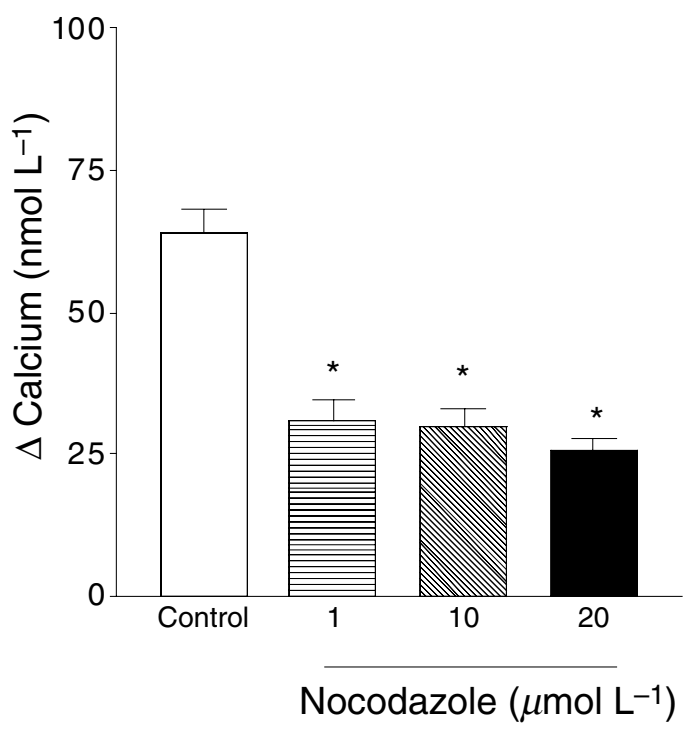

Figure 7 Effect of increasing nocodazole dose on capacitative calcium entry (CCE). Change in intracellular calcium due to CCE in control (white bar) compared with $1 \mu \mathrm{mol} \mathrm{L}^{-1}$, $10 \mu \mathrm{mol} \mathrm{L}^{-1}$ and $20 \mu \mathrm{mol} \mathrm{L}{ }^{-1}$ nocodazole after $120 \mathrm{~min}$ at $37^{\circ} \mathrm{C}$. Control cells had an increment of CCE ( $\Delta$ calcium) due to CCE of $63.9 \pm 4 \mathrm{nmol} \mathrm{L}^{-1}$ whereas nocodazole treatment yielded CCE of $31.0 \pm 3 \mathrm{nmol} \mathrm{L}^{-1}\left(1 \mu \mathrm{mol} \mathrm{L}{ }^{-1}\right.$, ANOvA ${ }^{\star} P<0.01$ vs control $), 29.7 \pm 3 \mathrm{nmol} \mathrm{L}^{-1}\left(10 \mu \mathrm{mol} \mathrm{L}{ }^{-1}\right.$, ANOva ${ }^{\star} P<0.01$ vs control), and $25.8 \pm 2 \mathrm{nmol} \mathrm{L}^{-1}\left(20 \mu \mathrm{mol} \mathrm{L}^{-1}\right.$, ANOVA ${ }^{\star} P<0.01$ vs control). More than 50 cells were examined in each control and treatment group from at least three separate culture preparations.

were similar in control and treated groups $\left(45 \pm 2 \mathrm{nmol} \mathrm{L}{ }^{-1}\right.$ Vs $\left.48 \pm 1 \mathrm{nmol} \mathrm{L}{ }^{-1}\right)$. Cells treated with nocodazole demonstrated a diminished CCE response $\left(30 \pm 2 \mathrm{nmol} \mathrm{L}{ }^{-1}, n=142\right.$ cells $)$ compared with the control CCE response $\left(77 \pm 6 \mathrm{nmol} \mathrm{L}^{-1}, n=118\right.$ cells, $P<0.01$ ) (Fig. 8A,B). The proportion of cells exhibiting CCE inhibition was significantly greater in the nocodazole-treated group $(89 \pm 2 \%, n=4$ separate 


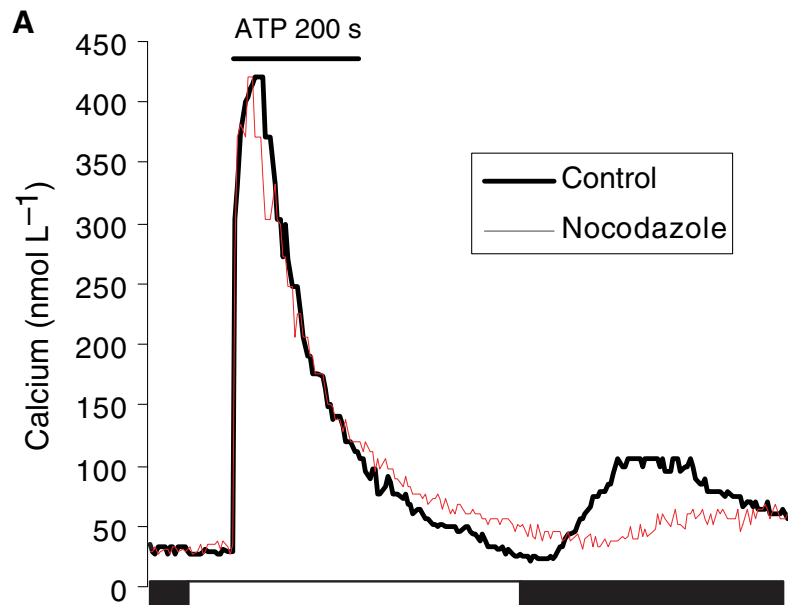

Time (s)

B
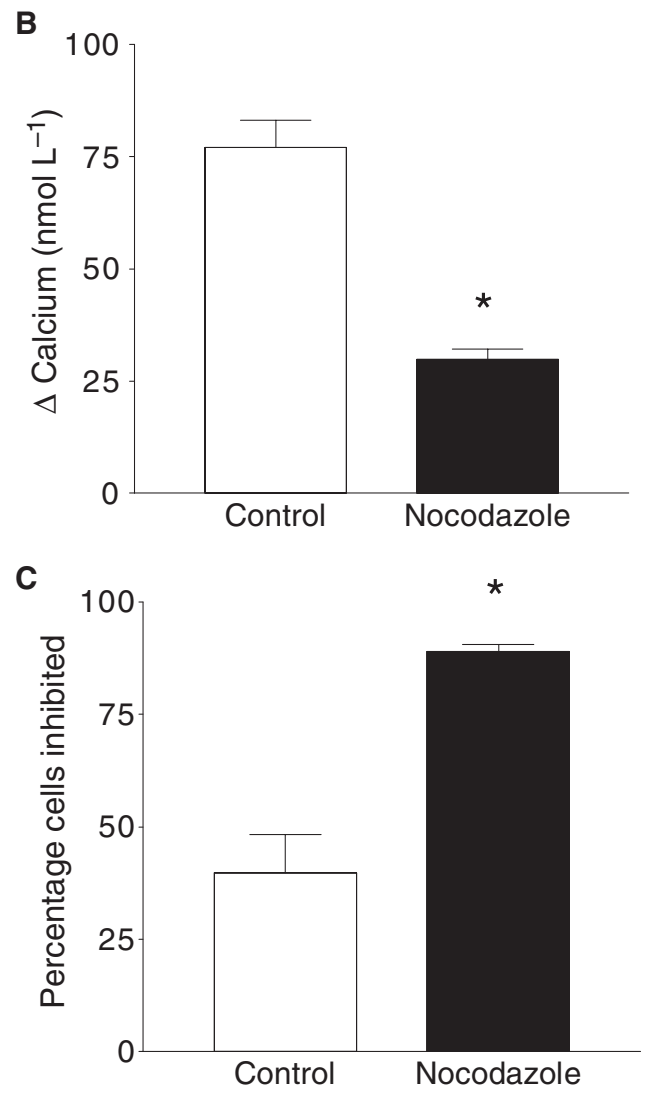

culture preparations) compared with control $(40 \pm 9 \%$, $n=4$ separate culture preparations, $P<0.05$ ) (Fig. 8 C).

\section{Rate of cation entry is altered by cytoskeletal disruption}

Barium was used in a separate group of experiments to examine cation entry from the external environment.
Figure 8 Effect of nocodazole treatment on capacitative calcium entry (CCE). (A) Representative single cell tracing of enteric glia (control - black tracing; nocodazole - red tracing). Cells were initially exposed to adenosine triphosphate $\left(100 \mu \mathrm{mol} \mathrm{L}{ }^{-1}\right)$ for $200 \mathrm{~s}$ in calcium-free buffer (white bar). Calcium was returned to the medium (black bar) with a second peak due to CCE. (B) Nocodazole-treated cells (black bar, $30 \pm 2 \mathrm{nmol} \mathrm{L}{ }^{-1}, n=142$ cells, ${ }^{\star} P<0.01$ ) demonstrated a diminished CCE response compared with control cells (white bar, $77 \pm 6 \mathrm{nmol} \mathrm{L}^{-1}, n=118$ cells) Cells examined were from at least three separate preparations. (C) Nocodazole-treated cells demonstrated a greater proportion of cells with inhibited CCE $\left(89 \pm 2 \%,{ }^{\star} P<0.05, n=4\right.$ separate culture preparations $)$ compared with control cells $(40 \pm 9 \%, n=4$ separate culture preparations).

These studies were carried out in separate experimental runs from at least three separate culture preparations. Barium, unlike calcium, cannot be sequestered intracellularly but shares the ability to interact with fura-2, making it a marker solely of cation influx. After depletion of intracellular calcium stores with ATP in the absence of extracellular calcium, barium was introduced to the perfusing medium for an interval of $250 \mathrm{~s}$. Barium more rapidly accumulated in control (11.2 $\pm 0.6 \mathrm{AU}$ (arbitrary units), $n=97$ cells) compared with cytochalasin D-treated cells $(5.9 \pm 0.5 \mathrm{AU}$, $n=108$ cells, $P<0.01$ ) (Fig. 9A). In addition, barium accumulated more rapidly in control $(9.3 \pm 1.5 \mathrm{AU}$, $n=43$ cells) compared with nocodazole-treated cells $(2.9 \pm 0.4 \mathrm{AU}, n=30$ cells, $P<0.01)$ (Fig. 9B).

\section{DISCUSSION}

The enteric nervous system has a major role in regulating the local gastrointestinal environment. ${ }^{1}$ Although the effector cells of the ENS have been believed to be solely gut neurones, recent work has shifted attention towards enteric glia. In this study, we demonstrate that calcium signalling in cultured enteric glia is modulated by cytoskeletal elements, microfilaments and microtubules. Our findings suggest that CCE is dependent, in part, on an intact cytoarchitecture. Enteric glia undergo distinct morphological changes with disruption of microfilaments and microtubules as assessed by light and fluorescent microscopy. The doses of cytochalasin D and nocodazole and incubating conditions are in concert with the ranges employed in a number of recent studies. ${ }^{10,14,15,19}$ These architectural changes did not affect measured basal $\left[\mathrm{Ca}^{2+}\right]_{\mathrm{i}}$. Moreover, the ability of glia to respond to ATP reflects their viability after pharmacological treatment. CCE is significantly reduced in cells treated with either cytochalasin D or nocodazole as measured by 

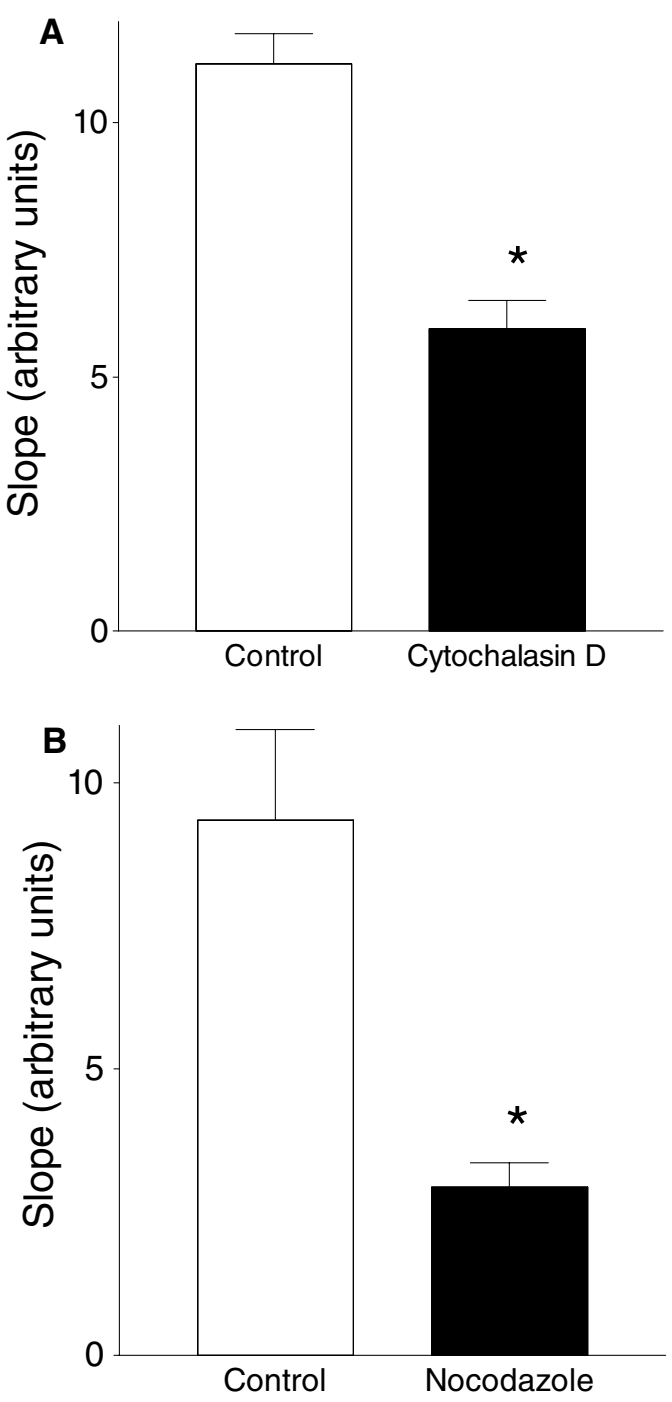

Figure 9 Effect of cytochalasin D and nocodazole on rate of cation re-entry following calcium store depletion. After depletion of intracellular calcium stores with adenosine triphosphate in the absence of extracellular calcium, barium was introduced to the perfusing medium for $250 \mathrm{~s}$. (A) Barium more rapidly accumulated in control (white bar, $11.2 \pm 0.6 \mathrm{AU}$ (arbitrary units), $n=97$ cells) compared with cytochalasin D-treated cells (black bar, $5.9 \pm 0.5 \mathrm{AU}, n=108$ cells, $\left.{ }^{\star} P<0.01\right)$. Three separate culture preparations represented. (B) Barium accumulated more rapidly in control (white bar, $9.3 \pm 1.5 \mathrm{AU}, n=43$ cells) compared with nocodazole-treated cells (black bar, $2.9 \pm 0.4 \mathrm{AU}, n=30$ cells, $\left.{ }^{\star} P<0.01\right)$. Three separate culture preparations represented.

fura-2 microfluorimetry. The results of the studies using barium as a marker exclusively for cation entry suggest that the inhibition of calcium influx following cytoskeletal disruption with cytochalasin $\mathrm{D}$ and nocodazole is due to a decreased rate of influx possibly attributable to structurally-dependent entry kinetics.
The cytoskeleton is a complex network composed of microfilaments, microtubules, and intermediate filaments. The cytoskeleton acts as an elastic mechanical conduit through which information and stimuli can be transmitted to the cell interior.

Recent work in cultured vascular smooth muscle cells demonstrated the existence of mechanically (stretch)-sensitive intracellular calcium stores insensitive to IP3 and potentially mediated through cytoskeletal elements. ${ }^{19}$ Cyclical stretch produced increases in intracellular calcium, which were inhibited by pretreatment with cytochalasin $\mathrm{D}$ but not by nocodazole. ${ }^{19}$ Studies in cultured rat astrocytes undergoing mechanical stimulation to evoke increases in intracellular calcium levels were attributed to an autocrine release of ATP and subsequent activation of the phopholipase C/IP3 pathway of calcium release. ${ }^{20}$ The authors postulate that mechanical stimulation induces the release of ATP through deformation of cytoskeletal elements. ${ }^{20}$ A review by Janmey details the effects of the cytoskeleton on cellular functions, including the regulation of transmembrane ion fluxes. ${ }^{21}$ Cytoskeletal regulation of ion flux has been proposed to occur via transduction of mechanical stress at the plasma membrane to membrane-localized ion channels. Membrane deformation may open or close these channels. This construct is consistent with the blunted CCE response demonstrated in our experiments as the disrupted cytoskeletal elements may alter signalling to membrane-based calcium channels. The possibility exists that mechanical stimulation via the continuous flow of the perfusion apparatus may contribute to cellular calcium signalling processes in myenteric glia. However, the rate of flow was constant and unchangeable in the current system; thus, the fixed rate of flow would likely supply a uniform stimulus in both treated and control groups. Similar initial basal calcium levels between control and treatment groups support a minimal or uniformly applied effect on glia from the perfusion system.

Numerous models have been proposed to explain CCE. The conformational coupling model, in which protein-protein interactions facilitate signal transduction from the intracellular calcium storage organelle and the plasma membrane calcium channel, has been the most widely investigated. The present study suggests that cytoskeletal scaffolding of polymerized molecules of actin and tubulin mediate a key portion of the transduction mechanism involved in signalling intracellular calcium depletion to the plasma membrane in myenteric glia. However, controversy exists regarding the role of the cytoskeleton in CCE. Blatter and Holda reported that in vascular endothelial cells cytoskeletal 
disruption with cytochalasin D obliterated CCE, while ATP-evoked calcium transients remained unchanged. ${ }^{14}$ Their results support a conformational coupling model of CCE, either through physical proximity of the plasma membrane and the endoplasmic reticulum or through transduction of information through intact microfilaments. In contrast, in NIH 3T3 cells, Ribeiro found that cytoskeletal disruption abolished only agonist-induced calcium release, while the CCE response was unaffected. ${ }^{15}$ The investigators concluded that abolition of agonist-induced calcium mobilization was based on an altered spatial relationship between phospholipase C and IP3 receptors, while CCE was mediated by a diffusible messenger. ${ }^{15}$ Most recently, in cultured vascular endothelial cells, capacitative calcium entry was found to require both IP3 receptor binding as well as an intact actin cytoskeleton. ${ }^{22}$

In astrocytes, Sergeeva has shown that cytoskeletal disruption with cytochalasin D attenuates cell calcium oscillations in response to ATP. ${ }^{10}$ This alteration in calcium signalling was attributed to a diminished CCE response in treated cells, which interfered with the refilling of intracellular calcium stores required for oscillations. Patterson proposed a dynamic secretionlike coupling model regulating CCE in DDT $\mathrm{DPF}_{1}$ - and A7r5 cells. ${ }^{23}$ In that study, a subcortical layer of Factin was chemically induced using both Calyculin A, a phosphatase inhibitor, and jasplakinolide, a membrane-permeant peptide. A peripherally-located ring of F-actin was reorganized subjacent to the plasma membrane with these agents. CCE was inhibited in treated cells but was restored after incubation with cytochalasin D in the Calyculin A-treated group. The authors proposed that instead of a static cytoskeletal architecture permanently coupling the endoplasmic reticulum (ER) to the plasma membrane, a dynamic, reversible scaffolding acts as the mediator between these structures. ${ }^{23}$ Rosado, in work performed on human platelets, similarly proposed that reversible trafficking in a manner akin to vesicle transport between the ER and plasma membrane is involved in CCE. $^{24}$

The distinct and sometimes conflicting findings in the investigation of CCE from the present study and in other published studies may in part lie in the differential distribution and content of cytoskeletal elements amongst different cell types and species. Furthermore, a given cell type may have a greater or lower dependence on the cytoskeleton to convey calcium signals compared with other cell types. Finally, the redundancy of nature suggests that multiple pathways may coexist to regulate such a vitally important biological mediator as calcium.
The results of our study demonstrate that enteric glial calcium signalling is dependent on an intact microfilament and microtubule cytoskeleton. In concert with the findings of other investigations into the role of the cytoskeleton in CCE in a diversity of cell types, we conclude that the cytoskeleton plays an integral role in communicating the state of intracellular calcium stores to facilitate their replenishment from the external environment. ${ }^{11,12,14,22,24}$ Hence, in myenteric glia, the cytoskeleton physically couples the plasma membrane and endoplasmic reticulum to facilitate calcium store repletion.

\section{ACKNOWLEDGMENTS}

This work was generously supported by National Institutes of Health 5RO1 DK41204-14 and T32 DK07698-09 and the Frederick A. Coller Surgical Society.

\section{REFERENCES}

1 Giaroni C, De Ponti F, Cosentino M, Lecchini S, Frigo G. Plasticity in the enteric nervous system. Gastroenterology 1999; 117: 1438-58.

2 Ruhl A, Franzke S, Collins SM, Stremmel W. Interleukin-6 expression and regulation in rat enteric glial cells. Am J Physiol Gastrointest Liver Physiol 2001; 280: G1163-71.

3 Maudlej N, Hanani M. Modulation of dye coupling among glial cells in the myenteric and submucosal plexuses of the guinea pig. Brain Res 1992; 578: 94-8.

4 Zhang W, Segura B, Lin T, Hu Y, Mulholland M. Intercellular calcium waves in cultured enteria glia from neonatal guinea pig. Glia 2003; 42 (in press).

5 Zhang W, Sarosi GAJr, Barnhart DC, Mulholland MW. Endothelin-stimulated capacitative calcium entry in enteric glial cells: synergistic effects of protein kinase C activity and nitric oxide. J Neurochem 1998; 71: 205-12.

6 Kimball BC, Mulholland MW. Enteric glia exhibit P2U receptors that increase cytosolic calcium by a phospholipase C-dependent mechanism. I Neurochem 1996; 66: 604-12.

7 Sarosi GA, Barnhart DC, Turner DJ, Mulholland MW. Capacitative $\mathrm{Ca}^{2+}$ entry in enteric glia induced by thapsigargin and extracellular ATP. Am I Physiol 1998; 275 (Pt 1): G550-5.

8 Putney JW Jr. A Model for receptor-regulated calcium entry. Cell Calcium 1986; 7: 1-12.

9 Berridge MJ. Capacitative calcium entry. Biochem J 1995; 312 (Pt 1): 1-11.

10 Sergeeva M, Ubl JJ, Reiser G. Disruption of actin cytoskeleton in cultured rat astrocytes suppresses ATP- and bradykinin-induced $\left[\mathrm{Ca}^{2+}\right]_{i}$ oscillations by reducing the coupling efficiency between $\mathrm{Ca}^{2+}$ release, capacitative $\mathrm{Ca}^{2+}$ entry, and store refilling. Neuroscience 2000; 97: 765-9.

11 Holda JR, Klishin A, Sedova M, Hüser J, Blatter LA. Capacitative calcium entry. News Physiol Sci 1998; 13: 157-63. 
12 Putney JW Jr, Broad LM, Braun FJ, Lievremont JP, Bird GS. Mechanisms of capacitative calcium entry. J Cell Sci 2001; 114 (Pt 12): 2223-9.

13 Delmas P, Wanaverbecq N, Abogadie FC, Mistry M, Brown DA. Signaling microdomains define the specificity of receptor-mediated $\operatorname{Ins} \mathrm{P}(3)$ pathways in neurons. Neuron 2002; 34: 209-20.

14 Holda JR, Blatter LA. Capacitative calcium entry is inhibited in vascular endothelial cells by disruption of cytoskeletal microfilaments. FEBS Lett 1997; 403: 191-6.

15 Ribeiro CM, Reece J, Putney JW Jr. Role of the cytoskeleton in calcium signaling in NIH 3T3 cells. An intact cytoskeleton is required for agonist-induced $\left[\mathrm{Ca}^{2+}\right]_{\mathrm{i}}$ signaling, but not for capacitative calcium entry. I Biol Chem 1997; 272: 26 555-61.

16 Alberts B, Bray D, Lewis J, Raff M, Roberts K, Watson J, eds. Molecular Biology of the Cell, 3rd edn. New York: Garland Publishing, 1994.

17 Yamamoto K, Kiss JZ. Disruption of the actin cytoskeleton results in the promotion of gravitropism in inflorescence stems and hypocotyls of Arabidopsis. Plant Physiol 2002; 128: 669-81.

18 Wolf KW, Winking $\mathrm{H}$. The organization of microtubules and filamentous actin in cytospin preparations of Sertoli cells from w/wwei mutant mice devoid of germ cells. Anat Embryol 1996; 193: 413-7.

19 Mohanty MJ, Li X. Stretch-induced $\mathrm{Ca}^{2+}$ release via an IP3insensitive $\mathrm{Ca}^{2+}$ channel. Am J Physiol Cell Physiol 2002; 283: C456-62.

20 Shiga $\mathrm{H}$, Tojima $\mathrm{T}$, Ito $\mathrm{E}$. $\mathrm{Ca}^{2+}$ signaling regulated by an ATP-dependent autocrine mechanism in astrocytes. Neuroreport 2001; 12: 2619-22.

21 Janmey PA. The cytoskeleton and cell signaling: component localization and mechanical coupling. Physiol Rev 1998; 78: 763-81.

22 Bishara NB, Murphy TV, Hill MA. Capacitative $\mathrm{Ca}^{2+}$ entry in vascular endothelial cells is mediated via pathways sensitive to 2 aminoethoxydiphenyl borate and xestospongin C. Br J Pharmacol 2002; 135: 119-28.

23 Patterson RL, van Rossum DB, Gill DL. Store-operated $\mathrm{Ca}^{2+}$ entry: evidence for a secretion-like coupling model. Cell 1999; 98: 487-99.

24 Rosado JA, Jenner S, Sage SO. A role for the actin cytoskeleton in the initiation and maintenance of storemediated calcium entry in human platelets. Evidence for conformational coupling. I Biol Chem 2000; 275: $7527-33$ 